\title{
Cardiocirculatory changes in hemorrhagic shock induced in pigs submitted to three distinct therapeutic methods ${ }^{1}$
}

\author{
Alterações cardiocirculatórias no choque hemorrágico induzido em suínos submetidos a três \\ terapias distintas
}

\author{
Gilberto Fernandes Silva de Abreu", Antônio Roberto Barros Coelho", José Lamartine de Andrade Aguiar", Sílvio Amorim \\ Moura Filho"II
}

${ }^{I}$ Preceptor, Department of Surgery, UFPE, Recife-PE, Brazil.

${ }^{\text {II }} \mathrm{PhD}$, Associate Professor, Department of Surgery, UFPE, Recife-PE, Brazil.

III MD Resident, Department of Surgery, Federal University Hospital, Recife, Brazil.

\begin{abstract}
Purpose: To evaluate and compare the response of pigs submitted to hemorrhagic shock and treated using three different strategies. Methods: Thirty-five Dalland pigs were divided into four groups: Control; Bleeding; Saline and Saline + Red Cell Concentrate. Parameters evaluated: heart rate (HR), mean arterial blood pressure (MAP) and central vein pressure (CVP).Hemorrhagic shock was induced by removing $(624.25 \pm 64.55),(619.30 \pm 44.94)$ and $(664.23 \pm 39.96) \mathrm{ml}$ of blood respectively, with the following treatment: Bleeding Group - zero volume replacement; Saline Group - replacement with $676 \mathrm{ml}$ of 0.9\% saline solution; Saline + Red Cell Concentrate Group - replacement with $440 \mathrm{ml}$ of $0.9 \%$ saline solution $+291 \mathrm{ml}$ of red cell concentrate. The treatment was evaluated after $10\left(\mathrm{~T}_{3}\right), 30\left(\mathrm{~T}_{4}\right), 45\left(\mathrm{~T}_{5}\right)$ and $60\left(\mathrm{~T}_{6}\right)$ minutes. Results: HR: No statistically significant difference was found between the Bleeding and Saline $[p=1.000]$, Bleeding and Saline + Red Cell Concentrate $[p=1.000]$, and Saline and Saline + Red Cell Concentrate $[p=0.721]$ groups. MAP; Significant differences were found between all the groups studied. CVP: No significant difference was found between the groups. Conclusion: Non-replacement and euvolemic resuscitation maintained a satisfactory hemodynamic pattern in controlled severe hemorrhagic shock in swine. The euvolemic replacement strategies exceeded the limit values of MAP for rebleeding.
\end{abstract}

Key words: Shock, Hemorrhagic. Trauma. Swine.

\section{RESUMO}

Objetivo: Avaliar e comparar as respostas cardiocirculatórias em suínos tratados por três terapias diferentes após choque hemorrágico. Métodos: Trinta e cinco suínos Dalland foram divididos em quatro grupos: Controle; Sangria; Salina; Salina + Concentrado de hemácias. Parâmetros cardiocirculatórios avaliados: Frequência cardíaca (FC), pressão arterial média (PAM) e pressão venosa central (PVC). O choque hemorrágico foi induzido retirando $(624,25 \pm 64,55)(619,30 \pm 44,94)$ e $(664,23 \pm 39,96)$ ml do volume sanguíneo. Terapias: Grupo Sangria - Sem reposição volêmica; Grupo Salina - reposição com $676 \mathrm{ml}$ de solução salina 0.9\%; Grupo Salina + Concentrado de hemácias - reposição com $440 \mathrm{ml}$ de solução salina $0,9 \%$ + $291 \mathrm{ml}$ de concentrado de hemácias. A avaliação do tratamento foi realizada aos $10\left(\mathrm{~T}_{3}\right), 30\left(\mathrm{~T}_{4}\right), 45\left(\mathrm{~T}_{5}\right)$ e 60 minutos $\left(\mathrm{T}_{6}\right)$. Resultados: $\mathrm{FC}$; Não houve diferença significativa entre os grupos Sangria e Salina $[\mathrm{p}=1,000]$; Sangria e Salina + Concentrado de hemácias [ $\mathrm{p}=1,000]$; Salina e Salina + Concentrado de hemácias [p=0,721]. PAM; Houve diferença entre todos os grupos. PVC; Não houve diferença entre os grupos estudados. Conclusão: Os procedimentos sem reposição e com reposição euvolêmica mantiveram padrão hemodinâmico satisfatório no choque hemorrágico grave controlado em suínos. As estratégias de reposição euvolêmica ultrapassaram os valores de PAM considerados limites para o resangramento.

Descritores: Choque Hemorrágico. Trauma. Suínos.

${ }^{1}$ Research performed at the Experimental Surgery Laboratory, Department of Surgery, Health Science Center, Federal University of Pernambuco (UFPE), Recife, Brazil.

\section{Introduction}

Hemorrhagic shock with blood loss of at least $40 \%$ of the individual's total blood volume may be secondary to a direct vascular lesion and/or the flow of plasma to damaged tissue. Tissue hypoperfusion leads to the reduction of available oxygen to the cell, hypothermia and metabolic acidosis. The physiopathological response to the state of hemorrhagic shock is characterized by vasoconstriction with a proportional growth in cardiac frequency (HR) and in mean arterial pressure (MAP). The current protocol for treatment advocated by the American College of Surgeons recommends the early use of two to three liters of saline solution as 
a resuscitation liquid for adults and $20 \mathrm{ml} / \mathrm{kg}$ for children who have abruptly lost more than $40 \%$ of their blood volume ${ }^{1}$.

This procedure is questionable, as studies demonstrate that conventional resuscitation with the replacement of hydrosaline fluids may cause dilutional coagulopathy and a subsequent increase in blood loss, with better results shown in hypotensive resuscitation in pig hemorrhagic shock models ${ }^{2,3}$.

Maintaining a hypotensive state with the careful administration of saline solution may reduce blood loss and may be preferable before definitive surgical repair of the bleeding site 4 . Similar results were obtained by other authors using saline solution up to a MAP of $50 \mathrm{~mm}$ of hg, with a lower mortality rate ${ }^{5,6}$. Furthermore, evidence exists in favor of the use of a 1:1 ratio of red cell concentrate and fresh plasma with an improvement of hemostasis and an increase in the survival rate. The objective of this study is to evaluate the cardiocirculatory responses to hemorrhagic shock therapy in pigs conducted without volemic replacement compared to those treated with isolated saline solution or saline solution combined with red cell concentrate.

\section{Methods}

Thirty five healthy pigs of the Dalland breed were divided into four Groups: Control $(n=5)$, Bleeding $(n=10)$, Saline Solution $(n=10)$ and Saline Solution + Red Cell Concentrate $(n=10)$, with respective weights of (23.40 \pm 1.29$),(22.70 \pm 2.34),(22.52 \pm 1.63)$ and (24.16 \pm 1.45$)$ kilograms.

Anesthesia was accomplished using the pre-anesthetic drug ketamine hydrochloride $(20 \mathrm{mg} / \mathrm{kg})$ injected in the ear pavilion with $0.9 \% \mathrm{ClNa}$ solution $\mathrm{t}(1 \mathrm{ml} / \mathrm{kg} / \mathrm{h})$; General anesthesia was accomplished with tiopental $(5 \mathrm{mg} / \mathrm{kg})$, ketamine hydrochloride $(10 \mathrm{mg} / \mathrm{kg})$ and pancuronium $(0.04 \mathrm{mg} / \mathrm{kg})$. Respiration under tracheostomy with mechanical ventilation was installed with oxygen with a $\mathrm{FiO}_{2}$ of $21 \%$. All the animals were submitted to experimental surgical intervention, the Swan ${ }^{5}$ model of hemorrhagic shock being induced with initial volemia estimated through the formula IBV (1) = body weight $(\mathrm{kg})$ X $5.5 \%$.

Electrocardiography monitoring was carried out, with catheterization of the left femoral artery for continuous measurement of mean arterial pressure (MAP) and internal jugular veins for measurements of central venous pressure (CVP) and volume replacement when suitable. In all groups except for the control group, serial bleeding was carried out at 10 and 13 minutes, with a total blood volume estimated at $50 \%$ of the circulating volume. In the Bleeding Group there was no replacement. In the Saline Group, replacement was carried out with $0.9 \% \mathrm{ClNa}$ solution with a flow of $6 \mathrm{ml} / \mathrm{kg} / \mathrm{min}$, whilst in the Saline + Red Cell Concentrate Group, replacement was carried out with $0.9 \%$ ClNa solution and with Red Cell Concentrate in the ratio of $1: 1.5$, with a flow of $6 \mathrm{ml} / \mathrm{kg} / \mathrm{min}$.

The parameters were evaluated 10 minutes after vascular access and at the following stages: $\left(\mathrm{T}_{0}\right)-$ zero minutes; $\left(\mathrm{T}_{1}\right)-3.5$ minutes - after removal of $1 / 3$ of $50 \%$ of the volume; $\left(\mathrm{T}_{2}\right)-07$ minutes - after removal of $2 / 3$ of $50 \%$ of the volume; $\left(\mathrm{T}_{3}\right)-10$ minutes - after removal of $50 \%$ of the volume, 30 minutes $\left(\mathrm{T}_{4}\right), 45$ minutes $\left(\mathrm{T}_{5}\right)$ and 60 minutes $\left(\mathrm{T}_{6}\right)$. At each stage $15 \mathrm{ml}$ of blood was collected for blood gas analysis. The statistical analysis of $\mathrm{T}_{4}, \mathrm{~T}_{5}$ and $\mathrm{T}_{6}$ (therapeutic management period) was accomplished through the application of the Bonferroni test on the mean values of parameters verified during the period of application of therapeutic methods, with a confidence level of $95 \%$. This study was approved by the Ethics Committee on Animal Experimentation of the Federal University of Pernambuco - UFPE.

\section{Results}

When compared variable HR, no significant differences was found between the following group: Bleeding (184.83 \pm 13.54$)$ versus Saline Solution (179.30 \pm 8.49$) \quad[p=1.000]$; Bleeding $(184.83 \pm 13.54)$ versus Saline Solution + red cell concentrate

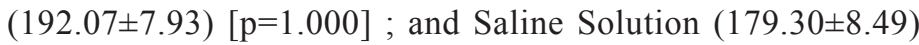

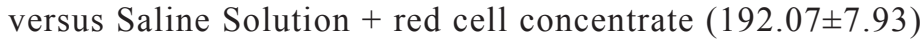
$[\mathrm{p}=0.721]$. A statistically significant difference was found between the groups Control (153.53 \pm 2.27$)$ e Bleeding (184.83 \pm 13.54$)$ [ $p=0.016]$, Control $(153.53 \pm 2.27)$ e Saline Solution (179.30 \pm 8.49$)$ [ $\mathrm{p}=0.048]$, Control $(153.53 \pm 2.27)$ and Saline Solution + red cell concentrate $(192.07 \pm 7.93)[\mathrm{p}=0.005]$, at all studied times after institution of therapeutic methods (Table 1 and Figure 1).

TABLE 1 - Mean values and standard deviations of HR, MAP and CVP obtained in the control, bleeding, saline and saline + red cell concentrate groups

\begin{tabular}{ccccc}
\hline & \multicolumn{4}{c}{ Groups } \\
\cline { 2 - 5 } Parameters & Control & Bleeding & Saline & $\begin{array}{c}\text { Saline }+ \text { red cell } \\
\text { concentrate }\end{array}$ \\
\hline HR & $153.53 \pm 2.27$ & $184.83 \pm 13.54$ & $179.30 \pm 8.49$ & $192.07 \pm 7.93$ \\
MAP & $117.67 \pm 1.15$ & $57.83 \pm 4.07$ & $85.50 \pm 5.41$ & $101.00 \pm 0.50$ \\
CVP & $-6.13 \pm 0.23$ & $-6.90 \pm 0.18$ & $-6.60 \pm 0.22$ & $-7.27 \pm 0.50$ \\
\hline
\end{tabular}




\section{MAP}

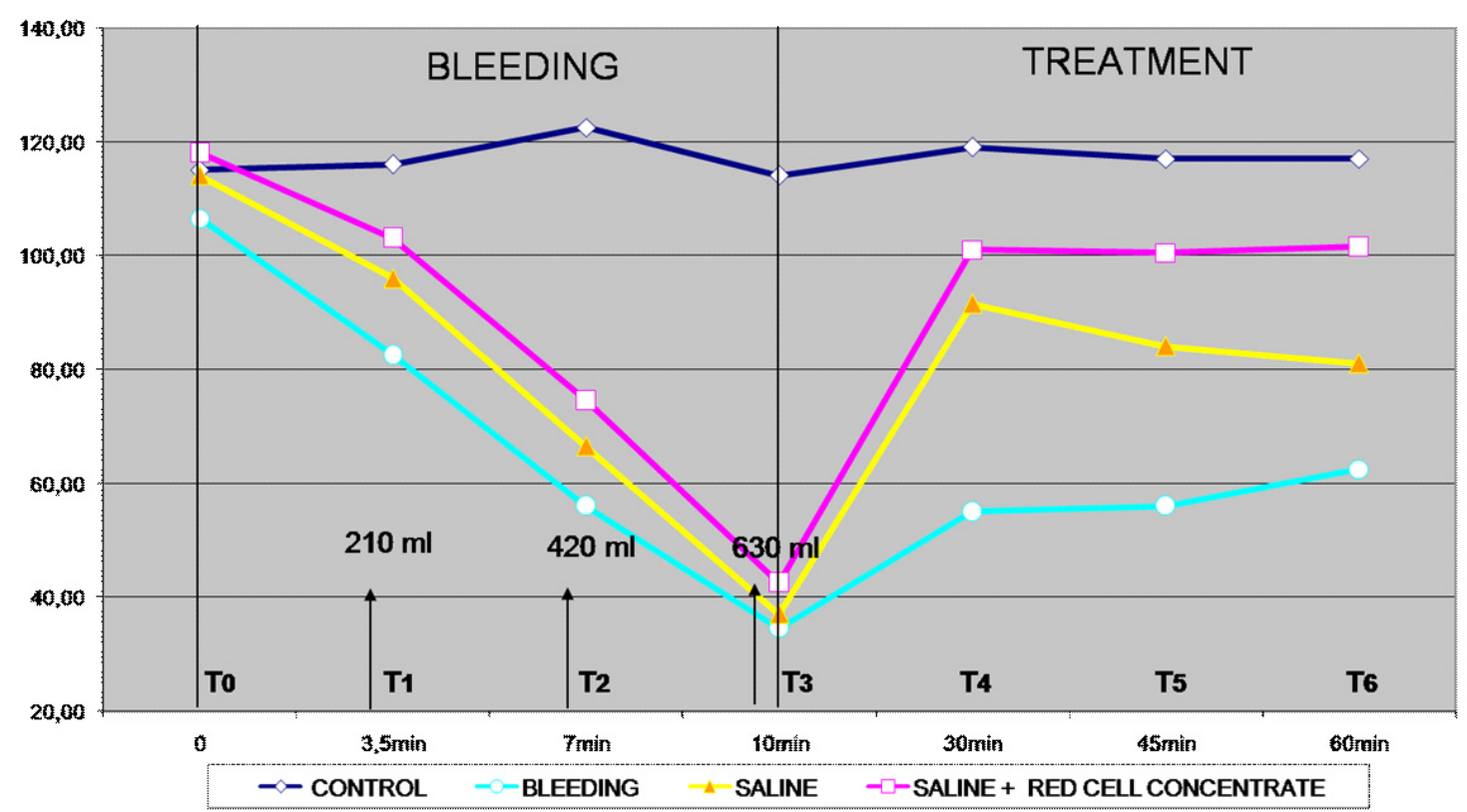

FIGURE 1 - Evolution of heart rate after hemorrhagic shock and respective therapy

Significant difference was found in mean values of MAP between the following groups: Control (117.67 \pm 1.15$)$ versus Bleeding (57.83 \pm 4.07$)$ [ $=0.000]$; Control $(117.67 \pm 1.15)$ versus Saline Solution $(85.50 \pm 5.41)$ [ $p=0.000]$; Control $(117.67 \pm 1.15)$ versus Saline Solution + red cell concentrate $(110.00 \pm 0.50)[p=0.002]$; Bleeding $(57.83 \pm 4.07)$ versus Saline
Solution ( $85.50 \pm 5.41)[\mathrm{p}=0.000]$, Bleeding $(57.83 \pm 4.07)$ versus Saline Solution + red cell concentrate $(110.00 \pm 0.50)[\mathrm{p}=0.000]$, Saline Solution $(85.50 \pm 5.41)$ e Saline Solution + red cell concentrate $(110.00 \pm 0.50)[\mathrm{p}=0.003]$, at all studied times after institution of therapeutic methods (Table 1 and Figure 2)

\section{HR}

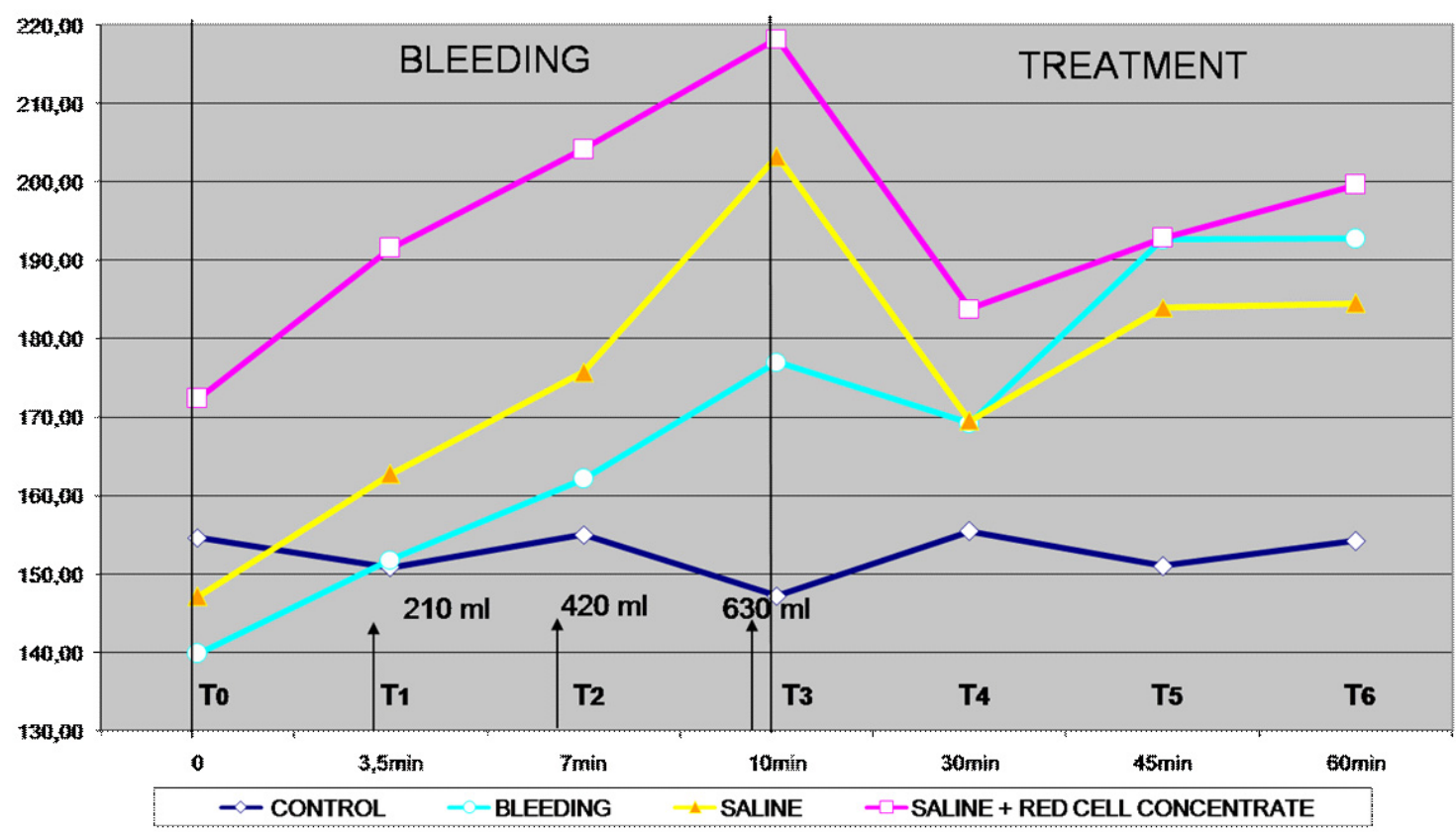

FIGURE 2 - Evolution of mean arterial blood pressure after hemorrhagic insult and employed treatment 
No statistically significant difference was found in mean values of CVP between the following groups; Control (-6.13 \pm 0.23$)$ versus Bleeding $(-6.90 \pm 0.18)[\mathrm{p}=0.420]$; Control $(-6.13 \pm 0.23)$ versus Saline Solution $(-6.60 \pm 0.22)[\mathrm{p}=0.620]$; Control $(-6.13 \pm 0.23)$ versus Saline Solution + red cell concentrate $(-7.27 \pm 0.50)$ $[\mathrm{p}=0.269]$; Bleeding $(-6.90 \pm 0.18)$ versus Saline Solution
$(-6.60 \pm 0.22)[\mathrm{p}=1.000]$; Bleeding $(-6.90 \pm 0.18)$ versus Saline Solution + red cell concentrate $(-7.27 \pm 0.50)[p=1.000]$; and Saline Solution $(-6.60 \pm 0.22)$ versus Saline Solution + red cell concentrate $(-7.27 \pm 0.50)[\mathrm{p}=1.000]$ at all studied times after institution of therapeutic methods (Table 1 and Figure 3 ).

\section{CVP}

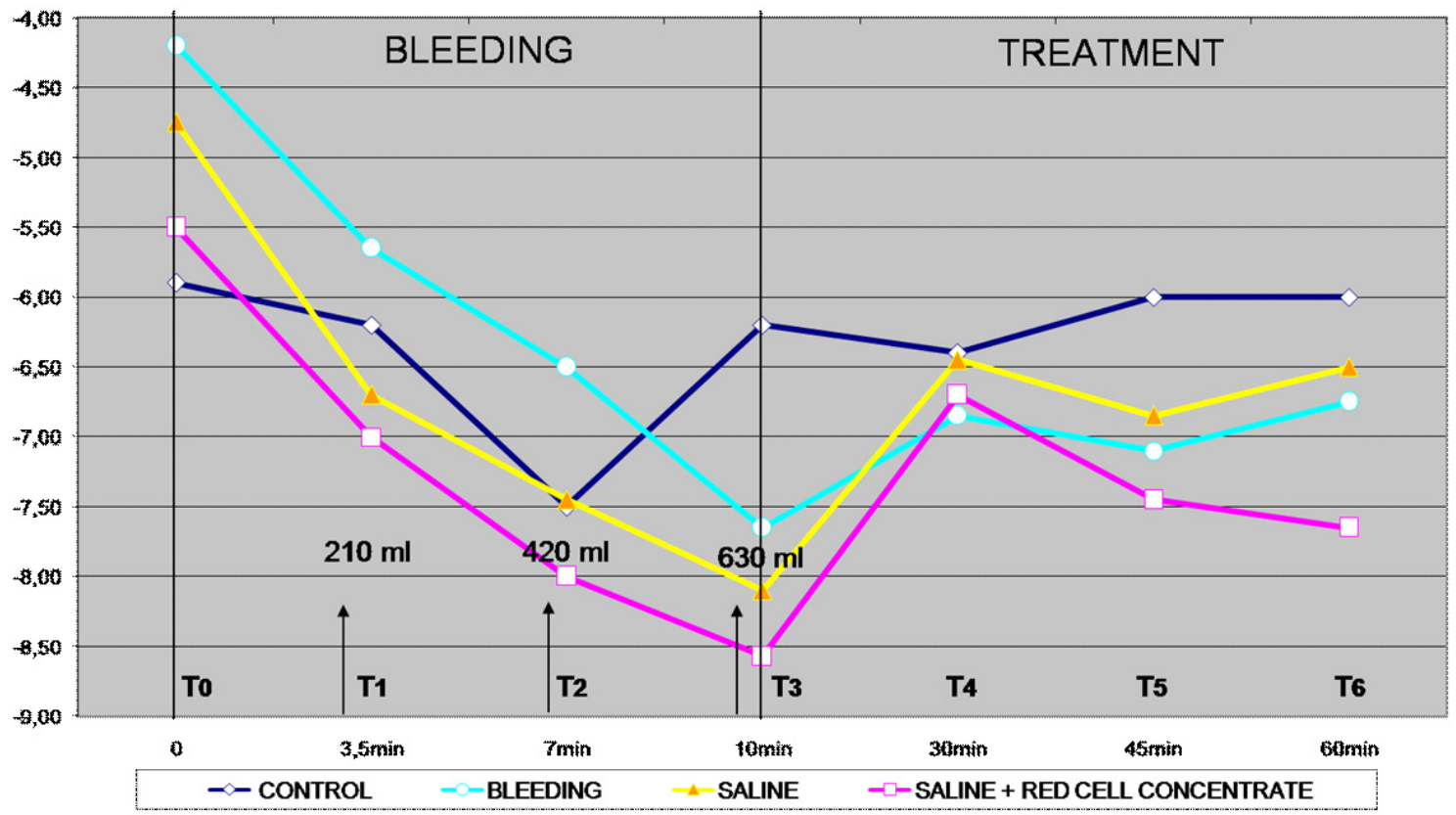

FIGURE 3 - Evolution of the central vein pressure after the hemorrhagic insult and resuscitation strategy

\section{Discussion}

Previous studies conducted on animals to evaluate hemodynamic response in hemorrhagic shock treatment have shown that the replacement of 1 to 1.5 times the lost volume with lactated ringer brought about effective resuscitation with superior survival rates compared to vigorous replacement and no treatment ${ }^{9}$. Experiments on rabbits showed that the hypovolemic resuscitation strategy reduced the seric concentration of tumor necrosis factor (TNF alpha) and interleucine 6 when compared to vigorous blood replacement ${ }^{10}$.

Wistar-Kyoto rats, when treated with the HDACI (histone deacetylase inhibitors) enzyme and without blood replacement after deep hemorrhagic shock, showed a greater rate of survival in the first 3 hours when compared to unresuscitated animals ${ }^{11}$. In this study, there was no difference in the therapeutic options employed concerning HR and CVP. The HR parameter showed a statistical difference between the Control group and the groups that underwent hemorrhagic shock. MAP showed a gradual recuperation of levels compatible with life, with steady growth in the Bleeding group, reaching mean values of $57 \mathrm{mmHg}$, considered to be the limit for rebleeding that was exceeded in Saline and Saline + Red Cell Concentrate Groups. The evolution of MAP revealed a two-phase pattern above the minimum level for rebleeding 5 in the Saline Solution Group, showing that replacement of blood volume with saline solution may produce a transitory response translated as improvement in pressure levels, evidence of endothelial dysfunction and the lowest remnant of the solution in the intravascular space ${ }^{12-15}$. The Saline Solution + Red Cell Concentrate group showed a stable response in MAP recuperation levels, maintaining these levels during the studied period of 50 minutes after the start of therapy. Zakaria et al. ${ }^{12}$ suggest that resuscitation strategies that contain blood are associated with a better preservation of hemodynamics, with a lower degree of microvascular dysfunction. Sondeen et al. ${ }^{5}$ show that a secondary hemorrhage event after fluid therapy can be predicted through MAP monitoring, establishing a safety margin for resuscitation while there is no control of the primary source of bleeding ${ }^{16}$. There is no difference in the CVP responses. The loss of $50 \%$ of the total blood volume of the animals studied produced transitory hemodynamic alterations without compromising the compensation mechanisms for the reduction of the intravascular content.

Considering the wide variety of resuscitation liquids currently available and the diverse ways in which organic injuries can cause deep hemorrhagic shock, it is recommended that the therapeutic approach be determined by an individual evaluation of each victim, contrary to the standardized and protocol approach recognized by some authors, services and entities. The ideal moment and quantity of liquid to be administered to hemorrhagic shock patients still remains undefined, a fact that determines the need for more controlled and randomized study, in order to establish a more effective strategy for blood replacement ${ }^{17-20}$. 


\section{Conclusion}

Non-replacement and euvolemic replacement procedures maintained a satisfactory hemodynamic pattern in this experimental model of controlled severe hemorrhagic shock in swine. When the source of bleeding was controlled, strategies of euvolemic replacement exceeded the limit values of MAP for rebleeding.

\section{References}

1. American College of Surgeons. Advanced trauma life support for physicians: instructor manual. Chicago. Am Col Surg. 2008;87-123.

2. Bickell WH, Bruttig SP, Millnamow GA, O'Benar J, Wade CE. The detrimental effects of intravenous crystalloid after aortotomy in swine. Surgery. 1991;110:529-36.

3. Kowalenko T, Stern S, Dronen S, Wang X. Improved outcome with hypotensive resuscitation of uncontrolled hemorrhagic shock in a swine model. J Trauma. 1992;33:349-53.

4. Bickell WH, Wall MJ, Pepe PE, Martin RR, Ginger VF, Allen MK, Mattox KL. Immediate versus delayed fluid resuscitation for hypotensive patient with penetrating torso injures. N Eng J Med. 1994;331:1105-9.

5. Sondeen JL, Coppes VG, Holcomb JB. Blood pressure at which rebleeding occurs after resuscitation in swine with aortic injury. J Trauma. 2003;54:110-7.

6. Xiao N, Wang XC, Diao YF, Liu R, Tian KL. Effect of initial fluid resuscitation on subsequent treatment in uncontrolled hemorrhagic shock in rats. Shock. 2004;21:276-80.

7. Hess JR, Holcomb JB. Transfusion practice in military trauma. Transfus Med. 2008;18:143-50.

8. Swan H. Experimental acute hemorrhage. Arch Surg.1965;91:390-406. 9. Liu L, Hu D, Chen H, Hu PH. The effect of different volumes of fluid resuscitation on traumatic-hemorrhagic shock at high altitude in the unacclimated rat. Shock.2004;21:93-6.
10. Yu YH, Zhao KS, Gong SP. Effect of limited volume resuscitation on hemodynamic changes in pregnant rabbit with hemorrhagic shock. Zhonghua Fu Chan Ke Za Zhi. 2008;43:50-3.

11. Shults C, Sailhamer EA, Li Y, Liu B, Tabbara M, Butt MU, Shuja F, Demoya M, Velmahos G, Alam HB. Surviving blood loss without fluid resuscitation. J Trauma. 2008;64:629-40.

12. Zakaria ER, Spain DA, Harris PD, Garrison RN. Resuscitation regimens for hemorrhagic shock must contain blood. Shock. 2002;18:567-73.

13. Watters JM, Brundage SI, Todd SR, Zautke NA, Stefater JA, Lam JC, Muller PJ, Malinoski D, Schreiber MA. Resuscitation with lactated ringer's does not increase inflammatory response in a swine model of uncontrolled hemorrhagic shock. Shock. 2004;22:283-7.

14. Cotton BR, Guy JS, Morris Jr. JA, Abumrad NN. The cellular, metabolic, and consequences of aggressive fluid resuscitation strategies. Shock. 2006;26:115-21.

15. Abu-Hatum O, Bashenko Y, Hirsh M, Krausz MM. Continuous fluid resuscitation for treatment of uncontrolled hemorrhagic shock following massive splenic injury in rats. Shock. 2002;18:574-9.

16. Edelman DA, White MT, Tyburski JG, Wilson RF. Post-traumatic hypotension: should systolic blood pressure of $90-109 \mathrm{mmHg}$ be included? Shock. 2007;27:134-8.

17. Stern SA. Low-volume fluid resuscitation for presumed hemorrhagic shock: helpful or harmful? Curr Opin Crit Care. 2001;7:422-30.

18. Jarrar D, Wang P, Knoferl MW, Ba ZF, Cioffi WG, Bland KI, Chaudry IH. Does early infusion of red blood cells after trauma and hemorrhage improve organ functions? Crit Care Med. 2000;28:3498-504.

19. Tremblay LN, Rizoli SB, Brenneman FD. Advances in fluid resuscitation of hemorrhagic shock. Can J Surg. 2001;44:172-9.

20. Kwan I, Bunn F, Roberts I. Timing and volume administration for patients with bleeding. WHO Pre-Hospital Trauma Care Steering Committee. Cochrane Database Syst Rev. 2003;CD 002245.

\section{Correspondence:}

Gilberto Fernandes Silva de Abreu

Avenida 17 de Agosto, 2483/2201

52061-540 Recife - PE Brazil

Phone: (55 81)3442-8692/3445-6627

gabreu01@uol.com.br

Conflict of interest: none Financial source: none

Received: August 10, 2009

Review: October 14, 2009

Accepted: November 17, 2009

\section{How to cite this article}

Abreu GFS, Coelho ARB, Aguiar JLA, Moura Filho AS. Cardiocirculatory changes in hemorrhagic shock induced in pigs submitted to three distinct therapeutic methods. Acta Cir Bras. [serial on the Internet] 2010 Jan-Feb;25(1). Available from URL: http:// $\underline{\text { www.scielo.br/acb }}$ 